\title{
BLACK V. CHRÉTIEN AND the Control of the Royal Prerogative
}

Noel Cox

\section{INTRODUCTION}

Conrad Black, a prominent publisher and businessman in both Canada and the United Kingdom, submitted his name for one of the peerages to be created for the new-model House of Lords following the House of Lords Act 1999. ' The rights and duties of peers depend entirely upon custom. ${ }^{2}$ The principal legal distinction of British peers is - or was - their right to sit and vote in Parliament. ${ }^{3}$ Not all peers however were Lords of Parliament (principally the Irish peers not also possessing another peerage entitling them to a seat), and some Lords of Parliament, the bishops, are not peers. ${ }^{4}$ Essentially, Black was seeking, and had been promised, a seat in the upper house of the British Parliament. ${ }^{5}$

His ennoblement received the endorsement of William Hague, then Leader of the Opposition, and obtained the necessary approvals in the United Kingdom. ${ }^{6}$ The British Prime Minister had sought the

This Act excluded hereditary peers and peeresses from the House of Lords, subject to a temporary stay for a nominal group of representative peers; House of Lords Act 1999 (U.K.), 1999, c. 34 , ss. 1,2 .

2 Berkeley Peerage Case (1861), 8 L.R. H.L. Cas. 21; 11 E.R. 333 .

Norfolk Earldom Case, [1907] A.C. 10, 17, per Lord Davey.

Ecclesiastical dignitaries have formed part of the House of Lords from the earliest times, though they were excluded from 1640 to 1661: Clergy Act 1640 (Eng.), 16 Chas. II, c. 27; Clergy Act 1661 (Eng.), 13 Chas. II, c. 2.

5 Life peers are appointed by letters patent of the Sovereign, sealed with the Great Seal, under the authority of the Appellate Jurisdiction Acts 1876-1947 (U.K.). Despite the Life Peerages Act 1958 (U.K.), 6 \& 7 Eliz. II, c. 21, the Crown of the United Kingdom still does not have the power to confer peerages for life. Creations must be in accordance with one or other of the statutory measures. See Wensleydale Peerage Case (1856), 5 H.L.C. 958; 10 E.R. 1181 . See also the Report as to the Dignity of a Peer of the Realm, vol. 5 (London: Her Majesty's Stationary Office, 1829) at 81.

6 S. Barwick, "Canadian Prime Minister block's Blacks life peerage" Daily Telegraph (London) (19 June 2001). The standard procedure for the creation of "working" peers to perform regular parliamentary duties - rather than as an honour - calls for the creation to be endorsed by the leader of approval of the Canadian government for Black's honour, which was given. ${ }^{7}$ Tony Blair, the Prime Minister, advised the Queen to confer the title upon Black. However, Jean Chrétien, Prime Minister of Canada, intervened, and advised the Queen to not confer the peerage on Black. ${ }^{8}$ The reasons given for the subsequent adverse advice to the Queen from Chrétien included the claimed long-standing Canadian opposition to titular honours, said to have been encapsulated in the Nickle Declaration of $1919 .{ }^{9}$

Black consequently sued the Prime Minister and the Attorney General of Canada. Although the Ontario Court of Appeal rejected Black's argument, the litigation has raised important constitutional questions. In particular, what happens when conflict occurs between the Crown's advisors, and to what extent can the British and Canadian Crowns be disentangled, given the commonality of person and the historic legal continuity of the two constitutions? This paper will begin with a review of the Black case, and will then examine these questions.

one of the three principal political parties. It will not, however, proceed unless and until it receives the approval of the Political Honours Scrutiny Committee, and of the Prime Minister, who advises the Queen to confer the title; House of Lords' Briefing Paper, "The Membership of the House of Lords," online: <www publications.parliament.uk/pa/ld/hlmems.pdf > There is now a House of Lords Appointments Commission, responsible for advising the Queen on the appointment of non-political members of the House of Lords, and for scrutinizing all nominations; online: <www.houseoflordsappointments commission.gov.uk/members.htm $>$.

By letter dated 9 June 1999; cited in Black v. Canada (Prime Minister) (2001), 199 D.L.R. (4th) 228 at para. 9 [hereinafter Black].

8 Barwick, supra note 6. It was the standard practice to seek the approval of the Canadian government when a Canadian citizen was to be honoured.

9 Canada, House of Commons Debates (22 May 1919). As a resolution of the House of Commons it was not binding on the Crown nor on Parliament, nor was it actually followed by all successive Canadian governments. For one example of many, R.B. Bennett, Prime Minister of Canada from 1930 to 1935 , was created a viscount in 1941 . There are numerous examples of lesser honours both before and since. 


\section{CiRCUMStances OF THE Litigation}

The appellant alleged that the Canadian Prime Minister intervened with the Queen to oppose his appointment and that, but for the Prime Minister's intervention, he would have received the peerage. Black sued the Prime Minister for abuse of power, misfeasance in public office and negligence. He also sued the Government of Canada, represented by the Attorney General of Canada, for negligent misrepresentation. He sought declaratory relief and damages of $\$ 25,000 . .^{10}$

Black sought three declarations at the Ontario Court of Appeal. First, that the Prime Minister and the Government of Canada had no right to advise the Queen not to confer an honour on a British citizen or a dual citizen. Second, that the Prime Minister committed an abuse of power by intervening to prevent him from receiving a peerage. Third, that the Government of Canada negligently misrepresented to Black that he would be entitled to receive a peerage if he became a dual citizen and refrained from using his title in Canada. The respondents acknowledged that the negligent misrepresentation claim against the Government of Canada could proceed to trial. However, they moved to dismiss all other claims against the Government of Canada and all claims against the Prime Minister. ${ }^{11}$

\section{THE QUESTIONS ASKED BY THE COURT OF APPEAL}

There were essentially three questions for the Court to determine. In the words of Laskin J.A., giving the principal judgment of the Court, the broad question raised by Black's pleading was whether it disclosed a justiciable cause of action against the Prime Minister. Was it plain and obvious that, in advising the Queen about the conferral of an honour on a Canadian citizen, the Prime Minister was exercising a prerogative power of the Crown? ${ }^{12}$ If so, was it plain and obvious that this exercise of the prerogative is not reviewable by the courts $?^{13}$ If the Prime Minister's exercise of the prerogative was reviewable, does the Superior Court have jurisdiction to grant declaratory relief? ${ }^{14}$

There was an important question of justiciability of the royal prerogative at stake. The royal prerogative has

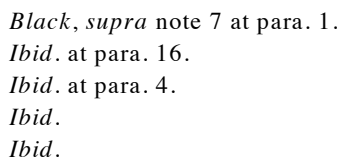

spread throughout the Commonwealth. ${ }^{15}$ It consists of the Crown's privileges and powers recognized or accorded by the common law. ${ }^{16}$ The prerogative can be regarded as a branch of the common law because decisions of courts determine both its existence and its extent. However, as some parts of the prerogative remain non-justiciable, it is perhaps better to regard the prerogative as not being part of the common law as such. The common law courts have been limiting the prerogative since Coke J. in the Case of Proclamations in $1611 .{ }^{17}$ But they are reluctant to interfere with the prerogative in certain areas. These include those parts of the prerogative which concern national security, the conduct of foreign policy, and the honours prerogative. These areas are non-justiciable. ${ }^{18}$

\section{THE FINDINGS OF THE COURT}

Black submitted that in Canada, only the Governor General can exercise the prerogative. ${ }^{19}$ The Court of Appeal could find no support for this proposition in theory or in practice. ${ }^{20}$

The Court noted that the 1947 Letters Patent Constituting the Office of the Governor General ${ }^{21}$ empowers the Governor General "to exercise all powers and authorities lawfully belonging to Us in respect of Canada."22 By convention, the Governor General exercises her powers on the advice of the Prime Minister or Cabinet. ${ }^{23}$ Although the Governor General retains discretion to refuse to follow this advice, in Canada that discretion has been exercised only in the most exceptional of circumstances. ${ }^{24}$ This was an unexceptional review of the constitutional position.

15 N. Cox, "The Dichotomy of Legal Theory and Political Reality: The Honours Prerogative and Imperial Unity" (1998) 14 Aust. J. L. Soc. 15 at 19 [hereinafter "The Dichotomy of Legal Theory"].

16 P.W. Hogg, Constitutional Law of Canada, looseleaf (Toronto: Carswell, 1995) at 1.9. See also Case of Proclamations (1611), 77 E.R. 1352 (K.B.) [hereinafter Case of Proclamations].

17 Case of Proclamations, ibid.

18 Council of Civil Service Unions v. Minister for the Civil Service, [1985] 1 A.C. 374 at 418 per Lord Roskill [hereinafter Council of Civil Service Unions]; R. v. Secretary of State for Foreign and Commonwealth Affairs, ex parte Everett, [1989] 1 All E.R. 655 at 660 per Taylor L.J.

19 Black, supra note 7 at paras. 24, 31.

$20 \quad$ Ibid at paras. 31-33.

21 Letters Patent, C. Gaz. 1947.I.3104 (Constituting the Office of Governor General of Canada).

22 Ibid.

23 See $e . g$. N. Cox, "The Control of Advice to the Crown and the Development of Executive Independence in New Zealand" (2001) 13 Bond L. Rev. 166 [hereinafter "Control of Advice"].

24 Relying on P. Lordon, Crown Law (Toronto: Butterworths, 1991) at 70; Black, supra note 7 at para. 31. 
The Court continued: "As members of the Privy Council, the Prime Minister and other Ministers of the Crown may also exercise the Crown prerogative." 25 This conclusion was based upon the judgment of Wilson J. in Operation Dismantle that the prerogative power may be exercised by cabinet ministers and therefore does not lie exclusively with the Governor General. ${ }^{26}$ This is perhaps an unfortunate choice of words. It does not mean that a minister can exercise a prerogative power, but rather that the exercise of the prerogative is based on the advice of these ministers.

In a brief analysis of the prerogative, the Court observed how in England the prerogative was gradually relocated from the sovereign personally to their advisors or ministers. For this reason it became normal to refer to those powers as belonging to the Crown. ${ }^{27}$ This gradual relocation of the prerogative is consistent with Professor Wade's general view of the Crown prerogative as an "instrument of government." ${ }^{28}$ The conduct of foreign affairs, for example, "is an executive act of government in which neither the Queen nor Parliament has any part." 29

Although this was a point on which the Court did not comment, it is suggested that this contention is not quite correct. It is true that Parliament has no inherent role in foreign affairs - in that it is ultimately the responsibility of the executive (though legislation may regulate certain aspects of foreign affairs, and Parliament has assumed some functions), ${ }^{30}$ - but the Queen and the Governor General do have a role, both legally and practically. ${ }^{31}$ The Crown must be seen as a

25 Black, ibid. at para. 32

26 Operation Dismantle Inc. v. The Queen, [1985] 1 S.C.R. 441 [hereinafter Operation Dismantle].

27 B. Hadfield, "Judicial Review and the Prerogative Power" in M. Sunkin \& S. Payne, eds., The Nature of the Crown: A Legal and Political Analysis (Oxford: Oxford University Press, 1999) at 199.

28 E.C.S. Wade, ed., Commentary on Dicey's Introduction to the Study of the Law of the Constitution, 9th ed (London: Macmillan, 1950).

29 F.A. Mann, Foreign Affairs in English Courts (Oxford: Clarendon Press, 1986) at 2. See also Barton v. Commonwealth of Australia (1974), 48 A.L.J.R. 161 at 172, cited in Black, supra note 7 at para. 32 .

30 Department of Foreign Affairs and International Trade Act, R.S.C. 1985 , c. E-22.

31 The legal role of the sovereign and Governor General includes approving the appointment of diplomatic envoys, and (in rare cases) the signing of treaties and the proclamation of war. The conduct of foreign affairs is in the name of the sovereign; $R \mathrm{v}$. Hampden (1637), 3 State Tr. 826. A practical consequence of this latter role can be seen in P. Hasluck, The Government and the People (Canberra: Australian War Memorial, 1970) at 4-12 The practical role of both include receiving state visitors and embarking upon state and official visits, and exercising the usual functions of a head of state in international law and practise; Ministry of Foreign Affairs and Trade, Presentation of corporation, in which several parts share in the authority of the whole, with the Queen as the person at the centre of the constitutional construct. ${ }^{32}$

Statutes have tended to use the terms "Her Majesty the Queen" and "the Crown" interchangeably and apparently arbitrarily. ${ }^{33}$ There appears to have been no intention to draw any theoretical or conceptual distinction. This may simply be a reflection of a certain looseness of drafting, but it may have its foundation in a certain lack of certainty felt by legal draftsmen as much as by the general public. ${ }^{34}$ This may perhaps be explained by briefly reviewing the evolution of the concept of the Crown. In essence, the difficulties highlighted by Black are those resulting from the evolution of the Crown, both as a post-imperial legacy, and as an abstract institution of government.

"The Crown" itself is a comparatively modern concept. As Maitland said, the king was merely a man, though one who did many things. ${ }^{35}$ For historical reasons the king or queen came to be recognized in law as not merely the chief source of the executive power, but also as the sole legal representative of the state or organized community. ${ }^{36}$

According to Maitland, the crumbling of the feudal state threatened to break down the identification of the king and state, and as a consequence Coke recast the king as the legal representative of the state. It was Coke who first attributed legal personality to the Crown ${ }^{37} \mathrm{He}$ recast the king as a corporation sole, permanent and metaphysical. ${ }^{38}$ The king's corporate identity ${ }^{39}$ drew

Credentials in New Zealand (Wellington: Ministry of Foreign Affairs and Trade, 1997); V. Bogdanor, The Monarchy and the Constitution (Oxford: Clarendon Press, 1995).

32 See N. Cox, "The Theory of Sovereignty and the Importance of the Crown in the Realms of The Queen" (2002) 2 Oxford U. Commonwealth L.J. 237.

33 For example, the word "sovereign" appears in New Zealand statutes only in the Sovereign's Birthday Observance Act 1952. In the Constitution Act 1986, s. 2, "Crown" is defined as "Her Majesty the Queen in right of New Zealand; and includes all Ministers of the Crown and all departments."

34 For this conceptual uncertainty, see J. Hayward, In Search of a Treaty Partner (Ph.D. Thesis, Victoria University of Wellington 1995) [unpublished]; interview with Sir Douglas Graham (24 November 1999).

35 F. Maitland, "The Crown as a Corporation" (1901) 17 L.Q. Rev. 131.

36 W. Stubbs, The Constitutional History of England, vol. 2, 4th ed. (Oxford: Clarendon Press, 1906) at 107.

37 Maitland, supra note 35. This can be seen in the Case of Proclamations, supra note 16.

38 It was as late as 1861 that the House of Lords accepted that the Crown was a corporation sole, having "perpetual continuance"; Attorney General v. Kohler (1861), 9 H.L. Cas. 654 at 671.

39 A corporation is "[a] number of persons united and consolidated together so as to be considered as one person in law, possessing the character of perpetuity, its existence being 
support from the doctrine of succession - that the king never dies. ${ }^{40}$ It was also supported by the common law doctrine of seisin, where the heir was possessed at all times of a right to an estate even before succession. ${ }^{41}$

Blackstone explained that the king is made a corporation to prevent in general the possibility of an interregnum or vacancy of the throne, and to preserve the possessions of the Crown entire. ${ }^{42}$ Thus the role of the Crown was eminently practical. In the tradition of the common law, constitutional theory was subsequently developed which rationalized and explained the existing practice.

Generally, and in order to better conduct the business of government, the Crown was accorded certain privileges and immunities not available to any other legal entity. ${ }^{43}$ Blackstone observed that "[t]he King is not only incapable of doing wrong, but even of thinking wrong; he can never mean to do an improper thing, in him is no folly or weakness." 44

Mathieson has proffered the notion that the Crown may do whatever statute or the royal prerogative expressly or by implication authorizes, but that it lacks any natural capacities such as those an individual or juridical entity may possess. ${ }^{45}$

constantly maintained by the succession of new individuals in the place of those who die, or are removed. Corporations are either aggregate or sole. Corporations aggregate consist of many persons, several of whom are contemporaneously members of it. Corporations sole are such as consist, at any given time, of one person only"; E.R. Hardy-Ivamy, Mozley and Whiteley's Law Dictionary, 10th ed. (London: Butterworths, 1988) at 109.

40 The theory that the king never dies was accepted during the reign of Edward II, that the demise of the Crown at once transfers it from the last wearer to the heir, and that no vacancy, no interregnum, occurs at all. See Stubbs, supra note 36 at 107.

${ }^{41} \mathrm{H}$. Nenner, The Right to be King: The Succession to the Crown of England, 1603-1714 (Chapel Hill: University of North Carolina Press, 1995) at 32.

42 W. Blackstone, Commentaries on the Laws of England, ed. by E. Christian, vol. 1 (New York: Garland Publishing, 1978) at 470. That Blackstone was at least partly incorrect can be seen in the development of a concept of succession to the Crown without interregnum of the heir apparent. Since this concept had been fully developed by the reign of Edward IV, it cannot have been the principal reason for the development of the concept of the Crown as a corporation sole.

43 B.V.Harris, "The 'Third Source' of Authority for Government Action" (1992) 109 L.Q. Rev. 626

44 Blackstone, supra note 42 at 254.

45 D.L. Mathieson, "Does the Crown Have Human Powers?" (1992) 15 N.Z. U. L. Rev. 118. Contrary case law includes Sutton's Hospital Case (1613), 10 Co. Rep. 23a; Clough v. Leahy (1905), 2 C.L.R. 139 at 156-57; New South Wales v. Bardolph (1934), 52 C.L.R. 455 at 474-75; R. v. Criminal Injuries Compensation Board, [1967] 2 Q.B. 864 at 886; Malone v. Metropolitan Police Commissioner, [1979] Ch. 344 at 366; Quebec (A.G.) v. Labrecque, [1980] 2 S.C.R. 1057 at
However, more recently, in M. v. Home Office, ${ }^{46}$ the English Court of Appeal held that the Crown lacked legal personality and was therefore not amenable to contempt of court proceedings. ${ }^{47}$ But it is precisely because in the Westminster-style political system there is not the continental notion of a state, nor (at least originally - and still in the United Kingdom) an entrenched constitution, ${ }^{48}$ that the concept of the Crown as a legal entity with full powers in its own right arose.

Although the House of Lords in 1977, in Town Investments v. Department of the Environment, ${ }^{49}$ accepted that the Crown did have a legal personality, it also adopted the potentially confusing practice of speaking of actions of the executive as being performed by "the government" rather than by "the Crown." ${ }^{50}$ The practical need for this distinction is avoided if one recognizes the aggregate nature of the Crown. ${ }^{51}$ "The government" is something which, unlike the Crown, has no corporate or juridical existence known to the constitution. Further, the legal definition of "the government" is both legally and practically unnecessary because the Crown provides a sufficient identity.

In Re Mason ${ }^{52}$ Romer J. in the High Court of England and Wales stated that it was established law that the Crown was a corporation, but whether a corporation sole (as generally accepted) or a corporation aggregate (as Maitland argued) was uncertain.

In Town Investments ${ }^{53}$ Lord Simon, with little argument, accepted that the Crown was a corporation aggregate, as Maitland maintained. This appears to be in accordance with the realities of the modern state, although it was contrary to the traditional view of the

1082; Davis v. Commonwealth (1988), 166 C.L.R. 79 (H.C.A.). $46 \quad$ [1992] 1 Q.B. 270.

47 However, in the House of Lords, Lord Templeman spoke of the Crown as consisting of the monarch and the executive, and Lord Woolf observed that the Crown had a legal personality at least for some purposes; M. v. Home Office, [1993] 3 All E.R. 537.

48 That is, one which claims for itself legal paramountcy, and which limits executive and legislative powers in such a way that the constitution itself, rather than any institution of government, becomes the focus of critical attention.

49 [1978] A.C. 359 at 400 per Lord Simon of Glaisdale (H.L.) [hereinafter Town Investments].

50 Ibid.

51 Some writers, following Town Investments, ibid., have preferred the expression "government" rather than "Crown" or "state." See e.g. Harris, supra note 43 at 634-35. The government has never been a juristic entity, so in trying to abandon one legal fiction in Town Investments, their Lordships adopted a new one; P. Joseph, "Crown as a Legal Concept (I)" [1993] N.Z. L.J. 126 at 129 [hereinafter "Legal Concept (I)"].

52 [1928] 1 Ch. 385 at 401.

53 Town Investments, supra note 49 at 400 
Crown. Thus, the Crown is now seen, legally, as a nexus of rights and privileges, exercised by a number of individuals, officials and departments.

Maitland believed that the Crown, as distinct from the king, was anciently not known to the law but in modern usage had become the head of a "complex and highly organised 'corporation aggregate of many' - of very many." ${ }^{54}$ In Adams v. Naylor,${ }^{55}$ the House of Lords adopted Maitland's legal conception of the Crown. ${ }^{56}$ In the course of the twentieth century the concept of the Crown succeeded the king as the essential core of the corporation, which is now regarded as a corporation aggregate rather than a corporation sole. ${ }^{57}$

The development of the concept of the aggregate Crown from the corporate Crown provides sufficient flexibility to accommodate the reality of government, without the need for abandoning an essential legal principle or grundnorm $^{58}$ in favour of a very undeveloped and inherently vague concept of "the government." 59 Thus, for reasons principally of convenience, the Crown became an umbrella beneath which the business of government was conducted.

The Crown has always operated through a series of servants and agents, some more permanent than others. The law recognizes the Crown as the body in whom the executive authority of the country is vested, and through which the business of executive government is exercised.

Whether we have a Crown aggregate or corporate, the government is that of the sovereign, ${ }^{60}$ and the Crown has the place in administration held by the state in other legal traditions. The Crown, whether or not there is a resident sovereign, acts as the legal umbrella

Maitland, supra note 35.

[1946] A.C. 543 at 555 (H.L.)

56 It has also been accepted by the Supreme Court of Canada: Verreault v. Quebec (A.G.), [1977] 1 S.C.R. 41 at 47; Quebec (A.G.) v. Labrecque, supra note 45 at 1082.

57 P. Joseph, "Suspending Statutes Without Parliament's Consent" (1991) 14 N.Z. U. L. Rev. 282 at 287.

58 In Kelsen's philosophy of law, a grundnorm is the basic, fundamental postulate, which justifies all principles and rules of the legal system and from which all inferior rules of the system may be deduced; M. Hayback, Carl Schmitt and Hans Kelsen in the crisis of Democracy between World Wars I and II (DrIur Thesis, Universitaet Salzburg 1990).

59 For a critique of these propositions generally see "Legal Concept (I)," supra note 51; P. Joseph, "The Crown as a Legal Concept (II)" [1993] N.Z. L.J. 179; F.M. Brookfield, "The Monarchy and the Constitution Today: A New Zealand Perspective" [1992] N.Z. L.J. 438.

60 This concept is alive today, in part as a substitute for a more advanced concept of the constitution; interview with Sir Douglas Graham (24 November 1999). under which the various activities of government are conducted. Indeed, the very absence of the sovereign has encouraged a modern tendency for the Crown to be regarded as a concept of government quite distinct from the person of the sovereign.

The separation of the Crown and its development in different countries - whilst retaining the same person as sovereign of each - has led to difficulties with respect to the exercise of the prerogative.$^{61}$ It is not always clear which prerogative is being exercised, or who has the right to advise the Crown on the exercise of that prerogative. ${ }^{62}$

It must be asked whether the right to advise the Crown is the same as the actual exercise of that prerogative. The Court of Appeal for Ontario has perhaps gone too far in saying, as Laskin J.A. did, that "I conclude that the Prime Minister and the Government of Canada can exercise the Crown prerogative as well." ${ }^{63}$ The royal prerogative remains with the Queen and the Governor General, though the right to advise the Crown is diffused.

In giving the judgment of the Court of Appeal, Laskin J.A. continued: "In my view, however, whether one characterizes the Prime Minister's actions as communicating Canada's policy on honours to the Queen, giving her advice on Mr. Black's peerage, or opposing Mr. Black's appointment, he was exercising the prerogative power of the Crown relating to honours." 64

Strictly, the Prime Minister was advising the Crown in the exercise of the prerogative, for it is the Crown, and not the Prime Minister, to which the honours prerogative belongs. It was equally nonjusticiable however. Holding that the exercise of the honours prerogative is always beyond the review of courts is not a departure from the subject-matter test espoused by the House of Lords in the Civil Service Unions case. ${ }^{65}$ Rather, as has been written elsewhere, it is faithful to that test. ${ }^{66}$

The basis for the continued non-justiciability of the honours prerogative appears to be founded in the absence of any legitimate expectation. As Laskin J.A. observed:

\footnotetext{
"The Dichotomy of Legal Theory," supra note 15 at 19.

"Control of Advice," supra note 23.

Black, supra note 7 at para. 33 .

Ibid. at para. 35.

Council of Civil Service Unions, supra note 18.

"The Dichotomy of Legal Theory," supra note 15 at 19, cited with approval in Black, supra note 7 at para. 58.
} 
The refusal to grant an honour is far removed from the refusal to grant a passport or a pardon, where important individual interests are at stake. Unlike the refusal of a peerage, the refusal of a passport or a pardon has real adverse consequences for the person affected. Here, no important individual interests are at stake. Mr. Black's rights were not affected, however broadly "rights" are construed. No Canadian citizen has a right to an honour. ${ }^{67}$

However, it would perhaps be more accurate to note that the surviving prerogatives which have been held to be non-justiciable have, in the approach adopted by the House of Lords in the Civil Service Unions case, ${ }^{68}$ a nature which is not amenable to judicial scrutiny. Honours are clearly of that nature, for the granting of honours involves "oral and political considerations which it is not within the province of the courts to assess." ${ }^{\circ 9}$

\section{QUESTIONS REMAINING}

The foregoing discussion may be taken to show that the honours prerogative, and by extension the other "political" prerogatives of the Crown (such as treatymaking, defence, mercy, dissolution of Parliament, appointment of ministers ${ }^{70}$ ) is non-justiciable. But the royal prerogative is exercised by the Queen or Governor General (in some instances the LieutenantGovernors) on the advice of responsible ministers, and are not the exclusive preserve of ministers - though they may sometimes appear to be. ${ }^{71}$

The major question which is raised by Black, and which was not addressed by the Court, was what happens when conflict occurs between the Crown's advisors. British honours are principally the concern of British ministers, and likewise Canadian ministers can advise the Queen with respect to Canadian honours. Whether Canadian ministers can advise the Queen with respect to Canadian citizens receiving British honours raises important constitutional questions. Whilst there may be no important individual interests at stake, the identification of the proper sources of advice to the Crown is critical. ${ }^{72}$

Monarchy concentrates legal authority and power in one person, even where symbolic concentration

67 Black, ibid. at para. 60

${ }_{68}$ Council of Civil Service Unions, supra note 18.

69 Operation Dismantle, supra note 26 at 465 , cited with approval in Black, supra note 7 at para. 62.

70 Council of Civil Service Unions, supra note 18 at 418 .

${ }^{71}$ When a Prime Minister calls an election, he or she is advising the Governor General to call an election, not doing so him- or herself.

72 "Control of Advice," supra note 23. alone remains. ${ }^{73}$ In the eighteenth and nineteenth centuries, this was the logic underpinning the belief in the unity of the Crown. The Imperial Crown was indivisible. "The colonies formed one realm with the United Kingdom," the whole being under the sovereignty of the Crown. ${ }^{74}$ This sovereignty was exercised on the advice of imperial ministers.

In his seminal work on the royal prerogative, Herbert Evatt showed how the unity of the Crown was the very means through which separateness of the Dominions was achieved. The indivisibility of the Crown meant the existence of royal prerogatives throughout the empire. The identity of those who could give formal advice to the Crown changed from imperial to dominion ministers - and little or no formal legal changes were needed for countries to change from colonies to fully independent nations. ${ }^{75}$

By 1919 most of the powers of the Crown abroad were exercised on the advice of local ministries in all the dominions and self-governing colonies. ${ }^{76}$ That this was not yet a complete transference can be seen by the argument of the New Zealand Prime Minister, William Massey, at the Imperial Conference of 1921. He maintained the principle that "when the King, the Head of State, declares war the whole of his subjects are at war." 77 Dominions might sign commercial treaties, but not those concluding a war. Some aspects of external affairs were still a matter for the imperial authorities. ${ }^{78}$

The right to advise the Crown in the exercise of the war prerogative was kept in the hands of British ministers, and the right to advise the Crown excluded imperial concerns such as nationality, shipping, and

73 "The attraction of monarchy for the Fathers of Confederation lay in the powerful counterweight it posed to the potential for federalism to fracture"; D. Smith, The First Principle of Canadian Government (Toronto: University of Toronto Press, 1995) at 8 , relying on W.L. Morton. Provincial powers grew as the provincial ministers were accepted as responsible advisers of the Crown in their own right.

${ }^{74}$ R.v. Secretary of State for Foreign and Commonwealth Affairs, [1982] Q.B. 892 at 911 per Denning M.R.

75 H. Evatt, The Royal Prerogative (Sydney: The Law Book Company, 1987).

76 See the "Borden Memorandum 1919," in A.B. Keith, Speeches and Documents on the British Dominions 1918-1931 (London: Oxford University Press, 1932) at 13 [hereinafter Speeches and Documents]. The position that a Canadian Lieutenant Governor was as much a representative of Her Majesty as was the Governor General was firmly established by the late-nineteenth century; see Maritime Bank of Canada v. Receiver-General of British Columbia, [1892] A.C. 437 at 443.

77 W. Massey (20 June 1921), in Speeches and Documents, ibid. at $59-62$.

78 Report of the Inter-Imperial Relations Committee, Imperial Conference (1926) Parliamentary Papers, vol. xi $1926 \mathrm{cmd}$ 2768 at 5 . 
defence. ${ }^{79}$ This was to change however, as the dominions had been given membership in the League of Nations after the First World War, and came to be regarded in international law as independent countries. ${ }^{80}$

The problem of the remaining limitations on dominion independence was examined at the Imperial Conference of 1926. The Report of the Inter-Imperial Relations Committee to the Conference included the famous declaration that the dominions

are autonomous Communities within the British Empire, equal in status, in no way subordinate one to another in any aspect of their domestic or external affairs, though united by a common allegiance to the Crown, and freely associated as members of the British Commonwealth of Nations. ${ }^{81}$

There had been uncertainty as to what precisely had been agreed in 1926, though initially most commentators simply assumed that British ministers would continue to provide the King's only source of constitutional advice. ${ }^{82}$ The former Australian Prime Minister, William Hughes, distinguished between sources of formal and informal advice, with the British government providing the former, the dominion governments the latter. ${ }^{83}$ Arthur Berridale Keith thought, however, that the suggestion that the King can act directly on the advice of dominion ministers was a constitutional monstrosity which would be fatal to the security of the position of the Crown.$^{84}$

However, the Irish government thought there was only a personal union of the Crown. ${ }^{85}$ If this were so,

79 Ibid.

80 At the Peace Conference after the end of the First World War, the dominions (and India) were represented by delegates; Rules of Representation at the Peace Conference of Paris, 1919, cited in Speeches and Documents, supra note 76 at 13. The Annex to the Covenant of the League of Nations, 1919, listed the British Empire as an Original Member of the League of Nations. This was described as including Canada, Australia, South Africa, New Zealand, and India (Speeches and Documents, ibid. at 30). Both of these indicated a transitional status for the dominions. By 1928, and the signing of the Treaty for the Renunciation of War (the Paris Pact), the independence of the dominions was clearer, as separate plenipotentiaries signed on behalf of the dominions (Speeches and Documents, ibid. at 407).

$81 \quad$ Imperial Conference (1926) Parliamentary Papers, vol. 111926 cmd 2768 at 2 .

82 E. Jenks, "Imperial Conference and the Constitution" (1927) 3 Cambridge L.J. 13 at 21; A.B. Keith, Responsible Government in the Dominions, vol. 1, 2d ed. (Oxford: Clarendon Press, 1928) at xviii [hereinafter Responsible Government].

83 Australia, H.R., Commonwealth Parliamentary Debates, vol.115 at 863 (22 March 1927). Compare Jenks, ibid. at 21.

84 Responsible Government, supra note 82 at xviii.

85 Some support for this view can be found in Roach v. Canada, [1992] 2 F.C. 173 at 177 (T.D.). then imperial ministers could have no role in advising the king with respect to any matter internal to a dominion. The Irish may not have reflected the majority view, but theirs made more sense than that, for example, of Hughes.

Once the principle was established that the dominions were equal with the United Kingdom, it was inevitable that the dominions should acquire the exclusive right to advise the Crown on matters which related exclusively to those dominions. This was to be gained in the course of the 1920s and 1930s, and finally settled in the $1940 \mathrm{~s}$. This was the only possible outcome of the doctrine of equality.

It was the Second World War that finally settled the question of whether there was a complete transfer to dominion ministers of the right to advise the Crown on matters which concerned the dominions, and therefore complete executive or political independence. ${ }^{86} \mathrm{It}$ would follow that in all matters with respect to British honours and British subjects, the Queen relies upon the advice of British ministers, and similarly upon the advice of Canadian ministers for Canadian subjects and Canadian honours. Keith's feared conundrum has come to pass. The Queen should act solely upon the advice of British ministers when awarding a British peerage ${ }^{87}$ If her Canadian Prime Minister offers her advice, it is to her as Queen of Canada. As Queen of Canada she is powerless to prevent the conferring of a British title, although she could consult with herself, wearing her other hat as it were.

In reality, the Queen would not be placed in the intolerable position which was narrowly avoided if her respective ministers - Canadian and British - were always able to reconcile their differences. Doubtless, the British Prime Minister did not insist on the conferral of Black's peerage.

But it may not always be possible to reconcile potential differences. Had Blair insisted upon advising the Queen to confer a peerage upon Black, the Queen would have had little choice but to accede to his wishes.

86 Canada and South Africa chose to make separate proclamations of war. Both were able to do so because in those dominions there had clearly been a delegation by the King to the Governor General of the prerogative to declare war and make peace, in Canada under the Seals Act 1939, R.S. 1985, c. S-6, and in South Africa, under the Royal Executive Functions and Seals Act 1934 and the Status of the Union Act 1934. After some uncertainty, both Australia and New Zealand followed these precedents. See Hasluck, supra note 31 at 149-51; New Zealand, Gazette (9 December 1941) at 3877.

87 As she did when conferring a peerage on the distinguished New Zealand judge Sir Robin Cooke in 1996. See N. Cox, "Lord Cooke of Thorndon" [1996] N.Z. L.J. 123. 
The peerage was in effect a British office, and as such wholly within the field of the British prerogative, exercisable on the advice of the British Prime Minister. Had a foreign sovereign sought to appoint Black to an office, the Canadian Prime Minister would have been equally unable to intervene. The Queen of Canada has no role in the creation of United Kingdom peers, and so could not prevent Black from being ennobled on the advice of Blair.

Unfortunately, it also partook of the nature of a titular honour, and as such was subject to the rules which govern the acceptance of Commonwealth and foreign honours. ${ }^{88}$

It is probably not coincidental that the 2001 Queen's Birthday honours list in the United Kingdom included two knighthoods for Canadians, both long resident in the United Kingdom. ${ }^{89}$ Perhaps it was a message to Jean Chrétien that he ought not to interfere with the British honours system. Perhaps it would be desirable to rewrite the Canadian policy and regulations on the acceptance of Commonwealth and foreign orders, decorations and medals ${ }^{90}$ to address this particular situation.

Ultimately, however, the difficulty arose because of a lack of clear understanding of the difference between the Queen's position as Queen of Canada and Queen of the United Kingdom. It would be as inappropriate for the Prime Minister of Canada to advise the Queen of the United Kingdom (on any matter), as it would be for the Prime Minister of the United Kingdom to advise the Queen of Canada.
88 Policy Respecting the Awarding of an Order, Decoration and Medal by a Commonwealth or a Foreign Government, P.C. 1998; Regulation Respecting the Acceptance and Wearing by Canadians of Commonwealth and Foreign Orders, Decorations and Medals, Secretary of State 1968.

89 Professor George Bain, Vice-Chancellor of The Queen's University Belfast, and Terence Matthews, for services to industry and to Wales. See London Gazette (16 June 2001) No. 56237, supp.1.

$90 \quad$ Supra note 88 .
Ultimately, Conrad Black did become a peer. In 2001 he was raised to the peerage of the United Kingdom $^{91}$ after he renounced his Canadian citizenship. ${ }^{92}$

\section{Noel Cox}

Lecturer in Law, Auckland University of Technology, Auckland, New Zealand
${ }^{91}$ G. Jones, "Conrad Black finally made a life peer" Daily Telegraph (London) (12 September 2001).

92 "Conrad Black to give up Canadian citizenship" Daily Telegraph (London) (19 May 2001). 